\title{
IRISH STUDIES IN SPAIN - 2005
}

\author{
Reviews by \\ José Francisco Fernández
}

\author{
Introduction \\ Metáforas de su tierra by María Amor Barros del Río \\ Joyceana: Literaria Hibernica by M.E. Jaime de Pablos \& J. M. Estévez Saá (eds.) \\ Las poéticas de James Joyce y Luis Martín-Santos by Marisol Morales Ladrón \\ La novela irlandesa del siglo XX by Inés Praga Terente (ed.) \\ Humour and Tragedy in Ireland by P. Trainor de la Cruz \& B. Krauel Heredia (eds.)
}

Copyright (c) 2006 by José Francisco Fernández. This text may be archived and redistributed both in electronic form and in hard copy, provided that the authors and journal are properly cited and no fee is charged for access.

\section{Introduction}

The first years of the 21st century have witnessed a remarkable increase in the number of scholarly publications in Spain related to Irish studies. It is not by chance that this period roughly coincides with the creation of AEDEI. The Spanish Association for Irish Studies has promoted Irish literature and culture in such a way that what previously constituted the commendable efforts of scholars working in isolation (with the exception of the Spanish James Joyce Association, with more than 15 years of continuous work) has now become a thriving field of studies. Universities such as Burgos, Barcelona, A Coruña and some others are centres for new projects and Ph.D. dissertations are read every year. The production of books on Irish themes has acquired a high level of specialisation too, as the selection of recent works included here will testify.

Still, there is plenty of work to be done. More provocative studies must be written (Inés Praga's essay on the novel in Northern Ireland commented on here is undoubtedly an example to follow). More translations into Spanish and

ISSN 1699-311X into other peninsular languages must be done.

Manuela Palacios' rendering of six Irish women poets into Galician in her book Pluriversos (Santiago: Follas Novas, 2003) is another example of a carefully edited bilingual volume. The year 2005 saw another edition of W. B. Yeats's poetry, Antología Poética (Barcelona: Lumen), which is always good news, but other Irish authors perhaps not so popular among Spanish readers are waiting their turn. Recent works such as Elena Jaime's translation of George Moore's The Wild Goose (Almería: Servicio de Publicaciones de la Universidad, 2003) indicate that there are reasons for hope in this sense, despite the many shortcomings: In the year of Samuel Beckett's centennial celebrations there are not many prospects of new publications on the "headmaster of the Writing as Agony school" as Martin Amis called him, and James Knowlson's superb biography Damned to Fame. The Life of Samuel Beckett (London: Bloomsbury, 1996) still remains to be translated into Spanish.

In any case, the seeds have been sown for a promising future of forthcoming publications on Irish subjects in Spain. Those commented on below will not disappoint the interested reader. 
Barros del Río, María Amor (2004) Metáforas de su tierra. Breve historia de las mujeres irlandesas, Oviedo: Septem Ediciones. ISBN: 84-95687-82-8

One of the great paradoxes in Irish history is that a nation which has been represented by feminine myths since ancient times has had its history written by men. As has been the case in most countries, the historical role of women has been silenced and what Amor Barros proposes in this book is to redress the balance and to rescue from oblivion the presence of women in this country's evolution from the Celtic era to our postmodern times.

One of the assets of the book lies in its capacity of synthesis: as the title suggests, this is a "brief history", and the author has compressed the plight of Irish women for more than two thousand years into no more than a hundred pages. It should be taken into account that her approach is an integral one, and the situation of women in each period is not treated as an isolated phenomenon but is fully contextualised, considering factors such as land, religion or colonialism.

The book is divided into eight main chapters, each dedicated to a particular historical period. After the introduction, the second chapter explains that in Celtic Ireland feminine figures closely connected to nature prevailed in the belief systems of the first inhabitants of the island. Historical records show, however, that it was a patriarchal society which diminished the position of women. The Celts considered women as "incomplete men" and their value depended on their husbands' position in society. Although there was no presence of women in the public sphere, Amor Barros explains that Celtic laws respected women's rights more than other societies of the same period.

From Norman Ireland, Amor Barros highlights the duality in the treatment of women, depending on whether they belonged to the group of Norman invaders, in which case they were less independent, or to the Celtic majority, among whom women had more freedom.

Chapter four deals with Ireland from the $14^{\text {th }}$ to the $18^{\text {th }}$ centuries. It was an increasingly militarised society in which women's position was relegated to the private domain. Among the changes that took place from the $17^{\text {th }}$ century onwards (English colonisation, anti-
Catholic laws, introduction of the English Common Law) Amor Barros is alert to events which left an imprint on people's imagination and affected their lives in an emotional way, such as the emergence of the Aisling, a poetical composition in which a crying woman waits for her rescuer beyond the seas, and which is now part of the collective memory of the Irish.

The author reveals that in the upper classes, women were relegated to their homes while in the lower classes they had a more active working role. In the $18^{\text {th }}$ century, due to their access to the libraries of the "Big Houses", some upper class women became writers, although using masculine pseudonyms. At the end of this century the only other options for women were emigration or joining a religious order.

Chapter five is probably the most complete section in the whole book, written with special attention to detail. Its focus is the $19^{\text {th }}$ century when, according to Amor Barros, the foundations of the Irish Free State were built. She first describes the general situation of the country, and later on women's specific problems. If the system known as "Familism" was the means to avoid the irruption of other people into one's class, this meant that land was not divided among the offspring, but inherited by just one son. For women this had negative effects, as only one daughter in each family could marry because of the cost of the dowry.

When explaining the Irish famine and the starvation of the peasantry Amor Barros writes that women were the first to suffer lack of jobs; they lost their position as labourers in the fields and their social status decreased, because their possibilities of marriage diminished. In this chapter data are provided on the work of women in domestic service, in industry and in the fields, although according to the author, during the $19^{\text {th }}$ century fewer Irish women worked outside the home. Other aspects that are dealt with are emigration, education and politics.

Frequent references are made throughout the book to the privileged position of the Catholic Church in the history of the country. In chapter six, which clarifies the situation of women during the Irish Free State, this influence was particularly relevant. According to Amor Barros, the new state of 1922 and the Catholic Church joined forces to limit women 
even more to the domestic sphere. Women were to be the transmitters of moral values within the family and their rights and sexuality were repressed.

Chapter seven analyses the consequences of De Valera's 1937 Constitution, which emphasized the concept of "purity" as an ideal for the new nation. Women's roles were reduced to child bearing and taking care of the family. Nevertheless, Amor Barros shows how many Irish women attempted to react against this patriarchal imposition.

The final chapter of the book briefly summarizes the changes in contemporary Ireland which have led to the abolition of restrictive laws, women's widespread access to education and their increasing participation in the labour market.

Jaime de Pablos, Maria Elena and José Manuel Estévez Saá, eds. (2005) Joyceana: Literaria Hibernica, Almería: Servicio de Publicaciones de la Universidad. ISBN: 848240-765-1

Though a relatively new field of research in Spain, Joycean studies are gaining ground in academic departments, and this book is one example of what is being done in this area among Spanish scholars. The editors of the volume, Maria Elena Jaime de Pablos, from the University of Almería, and José Manuel Estévez Saá, from the University of Seville, have gathered a collection of articles on the figure of James Joyce by some specialists working in Spanish universities. In the first section of the book, seven contributors deal with different aspects of the work of the great Irish writer. The second section is more varied, covering several aspects related to Irish literature in general.

Francisco García Tortosa, one of the leading figures of Joycean studies in Spain, dwells in the first chapter on the topic of James Joyce and Marxist criticism. He firstly explains that Joyce did not ascribe to any political ideology, although he might have been attracted to socialism in his youth. García Tortosa shows that Marxist critics generally considered Joyce's work disrespectfully. In the 1920s and 1930s, when Marxists regarded furthering the revolution as the main raison d'être for literature, they saw Joyce's novels as riddled with frivolities and populated by nonrevolutionary characters. The situation did not change substantially after the Second World War, when Joyce's work was either ignored or received coldly by critics. García Tortosa provides precise information on the position of well-known theorists such as Raymond Williams or Terry Eagleton, both of whom devoted scant attention to the Irish writer.

In the second chapter Rafael I. García León looks into Joyce's complex and tormented relationship with alcohol. This is followed by an article by Francisco Martínez Torres and Ian MacCandless on the operatic fragments mentioned in Ulysses. The authors of this paper place each piece in the context of the novel, revealing that the music and the lyrics are perfectly integrated in the development of the action at the point where they appear.

In the fourth chapter of the book Margarita Estévez Saá studies the figure of the mother in Joyce's work. In her opinion, the mother was characterised by her absence in Victorian literature as, according to the ideology of the time, it was necessary for her to disappear so that the main (male) character could develop. In the first decades of the twentieth century, Margarita Estévez Saá explains, the figure of the mother was vindicated, mainly by female writers, but Joyce also did justice to the multidimensionality of women in his work, presenting rich and complex female characters in his novels. Margarita Estévez Saá makes a revision of Joyce's main works, exploring the peculiar characteristics of mothers, from Stephen's mother in A Portrait... to Anna Livia Plurabelle in Finnegans Wake.

In chapter six Francisco Javier Quintana Álvarez and Rafael I. García León write about bullfighting in Ulysses. Taking as a starting point two references to bullfighting in $\mathrm{La}$ Línea in Joyce's novel, the authors investigate the actual facts on which the Irish writer could have based his comments.

Benigno del Río Molina is the author of the following article, and he compares chapter sixteen of Ulysses and a fragment of Las Meninas, the famous painting by Diego Velázquez. The author of the paper argues that, just as Velázquez carelessly painted a particular scene on purpose, Joyce similarly wrote the Eumeo chapter "badly". In both cases their aim was to enhance the rest of the work by comparison and thus highlight the perfect, accomplished quality of their creation.

In the final chapter of this section Juan Ignacio Oliva traces the influence of Joyce in 
the novels of two writers from very different origins, Amit Chaudhuri, born in India, and Shyam Selvadurai, born in Sri-Lanka. For Juan Ignacio Oliva, their novels construct a postcolonial künstlerroman or portraits of would-be artists, and they share structural and thematic elements that are clearly Joycean.

In the second part of the book, nine articles explore different aspects of Irish literature. The ample range of topics may suggest that, apart from Joyce, other kinds of writing from Ireland also provoke a positive response among scholars in Spain: Adolfo Luis Soto Vázquez studies the images of Ireland in Maria Edgeworth's Castle Rackrent. Anne MacCarthy comments on the national characteristics of the works of Lady Morgan and William Carleton. Nazareth García Seijas writes on the topic of masculinity in the work of W. B. Yeats. Ingrid Mosquera Gende compares the translations to Spanish and Galician of Yeats's Cathleen Ni Houlihan. María José López Córdoba approaches the articles of Brian O' Nolan (Flann O'Brien) in The Irish Times. José Luis Vázquez Marruecos and Inmaculada del Árbol Fernández deal with the classical world in contemporary Irish poetry. Susana Domínguez Pena studies the meeting of past and present in Brian Friel's Philadelphia, Here I Come! David M. Clark considers the concept of paralysis in Eoin McNamee's novel The Blue Tango (2000) and the volume closes with an article by José Manuel Estévez Saá, who makes a close analysis of Joseph O'Connor's novel Star of the Sea (2002).

\section{Morales Ladrón, Marisol (2005) Las poéticas de James Joyce y Luis Martín- Santos. Aproximación a un estudio de deudas literarias, Bern: Peter Lang. ISBN: 3-03910- 357-1}

Luis Martín-Santos was a Spanish writer who published only one novel, Tiempo de Silencio (1962), before his premature death in a car accident in 1964. Nevertheless the impact of this novel was so enduring that his work became a symbol of the new horizons for young Spanish literature, emerging at last after decades of stagnation during the Francoist regime.

As Marisol Morales Ladrón writes in the introduction to her book, Martín-Santos was the first Spanish writer to initiate a process of renewal in post-war Spanish fiction and he made ample use of Joycean influences and innovations. Although this study is firmly located in the field of comparative literature, Morales Ladrón aims to go beyond a mere comparison of two individual writers. Rather than embarking on a restrictive, source-hunting exercise, the author carries out the task of explaining the contextualization of both writers in their own traditions, producing a complete analysis of all the factors surrounding the writing process. The book is a revised version of the author's Ph.D. dissertation, and the academic origin of the text is made clear in the systematisation and precision that Morales Ladrón has imposed on an already vast body of material. No critical term is used lightly, no new concept is introduced without a previous historical assessment. The information provided on critical theory, literary movements, editions and even translations within the main body of the text and in the final bibliographic sections testifies that this is a work of true scholarship.

The book is divided into six chapters, the first of which deals with the literary production of both writers. Though James Joyce's life and works are well-known, it may be revealing for the reader to discover the biographical details Morales Ladrón offers about Martín-Santos: his ground-breaking work as a psychiatrist, his clandestine activities in the Socialist Party, for which he was arrested, his problems with censorship, etc.

Martin-Santos left an even more experimental novel unfinished, Tiempo de Destrucción (published 1975), and the collection of his assorted writings, Apólogos (1970), was published posthumously.

In this first chapter a close comparison is drawn between Joyce's Ulysses and MartínSantos's Tiempo de Silencio. Morales Ladrón points out the similarities between both fictions (predominance of the characters' inner mind over external action, concentration in time, fragmentation, urban journeys). However she also stresses a basic difference: while Ulysses is universal and subversive from the very beginning, Tiempo de Silencio is very much involved in a particular time and place, due to Martín-Santos's political commitments. The Spanish writer's novel, moreover, stems from a traditional idea of the genre, although he introduced experimental devices and techniques in his narrative. 
Chapter two analyzes the international literary relations that, in a wide sense, concerned the works of Joyce and MartínSantos. Of special interest in this chapter is section 2.3., as it describes the evolution of James Joyce's work in Spain, from its reception in the early twenties, through the cultural wasteland of the forties and fifties, to the new possibilities that it represented for the writers of the sixties.

Chapter three investigates the defining traits of Modernism, because this is the movement that, forty years later, Martín-Santos would turn to in order to break with the prevailing social realist novel in Spain. A clear distinction between what is known as Modernism in the English-speaking world and "Modernismo" in Hispanic letters is included in this chapter.

Chapter four considers Ulysses and Tiempo de Silencio from a generic point of view, and both are seen in the light of the total novel, the polyphonic novel and the antinovel. Morales Ladrón also compares Joyce's A Portrait of the Artist as a Young Man with Martín-Santos's Tiempo de Destrucción, using the concept of bildungsroman as a literary frame.

Chapter five focuses on the modern city (Dublin and Madrid) as the representative setting of modernist poetics. Although Joyce famously said that in case of destruction Dublin could be rebuilt from the descriptions he made of it in Ulysses, the truth is that he created a fictional construct based on real facts. Morales Ladrón insists on the fact that Joyce's Dublin is a "discursive" city, conceived with a symbolic function. Joyce also had the idea of using Dublin to represent the plurality of human existence; he had ambitions of immortality for his native city. Martín-Santos's description of Madrid is less explicit than Joyce's portrayal of Dublin. Though both works make poetic use of space, in Tiempo de Silencio the city leaves a deterministic imprint on the individual. Furthermore, the Spanish writer's presentation of Madrid lacks a universalizing aim.

Finally, the last chapter pays attention to the formal aspects in the fiction of both authors under discussion. Morales Ladrón analyzes the different methods of presentation of the characters' inner thoughts in Ulysses and Tiempo de Silencio, concluding that both works can be defined as Stream of Consciousness novels.
Praga Terente, Inés, ed. (2005) La novela irlandesa del siglo $X X$, Barcelona: PPU. ISBN: 84-477-0915-9

The relationship of Irish novelists with the genre in which they express themselves is nowadays free from anxiety, but this has not always been the case. Since the beginning of the nineteenth century the writer who chose this literary form was subject to a wide range of pressures, including the nationalistic discourse, the readership it was addressed to, the constraints imposed by religion or the strength of the short story, thought to be more congenial to the Irish mood.

However there is such thing as an Irish tradition of the novel which, according to the editor of La novela irlandesa del siglo $X X$, must be considered by itself and free from the conditioning factors of the English novel or continental models in order to understand its singularity. Such an approach is what Inés Praga proposes in this volume, which is motivated by a lack of specialized publications in Spain.

The title of the first chapter, "En torno a la novela irlandesa. Apuntes para una tradición", by Inés Praga, may be misleading, as this is not a mere compilation of notes, but a rigorous and fully documented study of the Irish novel in the last two centuries. In a highly readable style and with an engaging argumentation Praga studies the conditions which have made the Irish novel such an elusive term, despite counting with some of the best practitioners of the form in the English language. Praga rightly asserts that in the nineteenth century the novel in Ireland was sceptical of its own viability as a genre. It was difficult to evade the social instability which prevented the formation of a middle class and therefore an autochthonous readership.

Beginning with the "Big House" novel, initiated by Maria Edgeworth's Castle Rackrent (1800), Praga traces the development of the genre, reaching the dense novelistic production of the $20^{\text {th }}$ century. Authors and novels are set in their historical and cultural context, as when the reader is told that the Irish Literary Renaissance implied the marginalization of the novel, or that the passing of the Censorship of Publications Act (1929) brought about an increase of fantastic literature.

$\mathrm{M}^{\mathrm{a}}$ Amor Barros del Río's chapter "Nombrar lo innombrable. Mujeres y literatura 
en Irlanda" provides valuable insights into the work of Irish women writers from the first exponents of the form (Frances Chamberlaine, Lady Morgan, etc.) to the young authors of today (Emma Donoghue), revealing in most cases a voice of courage which struggled to be heard in unfavourable circumstances. Every important author, and others who do not normally appear in academic courses, deserves a close analysis in Amor Barros's account, explaining the significance of relevant works such as Grania (1892) by Emily Lawless, which broke with the traditional ending for women rebels in fiction. Particularly perceptive is her synthesis of The Real Charlotte (1894) by Somerville and Rose, as a novel which portrays a psychological complexity and an incipient feminist consciousness unknown in the $19^{\text {th }}$ century novel.

Leonardo Pérez García examines in "Representaciones de Dublín en la novela irlandesa contemporánea" how Dublin has been depicted in recent Irish fiction. The Irish capital, Leonardo Pérez explains, had lacked an urban identity until the nineteen sixties because of the permanence of rural conservative values. It was from that decade onwards that an urban consciousness began to form in the imagination of writers and city dwellers simultaneously. He begins his exposition with the analysis of two novels set precisely in that time: 44. A Dublin Memoir by Peter Sheridan, and The Mummy, by Brendan O'Carroll. These are novels which present working class families surviving in the city, with religion still playing a fundamental part in their lives. The next group of novels that Leonardo Pérez comments upon, set in the nineteen eighties, reflect an urban society which has lost its former certainties. In the last section he focuses on the work of Roddy Doyle, a Dubliner who has created a fictitious suburb for his native city.

In the fourth chapter, entitled "“A Treasury of Irish Melodies'. Secretos y mentiras en las novelas de Patrick McCabe", Ana Esther Rubio Amigo considers the work of Patrick McCabe, one of the most transgressive novelists writing in Ireland today. A spirit of disaffection pervades the novels of this writer, determined as he is to dismantle all the official tenets upon which an oppressive ideology has been built. Ana Esther Rubio firstly examines McCabe's "Black Trilogy", consisting of The
Butcher Boy (1992), The Dead School (1995) and Breakfast on Pluto (1998). In these novels the author shatters Ireland's cultural stereotypes instilled by De Valera's governments, creating in his fictional world the reverse of ideal families: alcoholic fathers, women unable to care for their families and insane children. McCabe's next novel Emerald Germs of Ireland (2001) subverts once more the "emerald gems" that for the author suffocated the Irish in the past.

In the fifth and final chapter, "La Novela del Norte", Inés Praga addresses the thorny issue of the novel in Northern Ireland. There are, she says, problems of terminology, of geographical delimitation and of a fundamental lack of specialised studies on the matter. Most scholars do not consider the literature of Northern Ireland in isolation, but maintain a cultural continuity between North and South. An honest approach to the study of the novel of the North, Praga writes, must consider not only the relationships with the Republic, but the connections with Britain as well. Her analysis, moreover, demonstrates the necessity of using a variety of lenses to understand a plural reality such as the one described in the pages under consideration. The main part of the essay is devoted to the reassessment of the novel in Northern Ireland from the $19^{\text {th }}$ century to our time.

Trainor de la Cruz, Patricia and Blanca Krauel Heredia, eds. (2005) Humour and Tragedy in Ireland, Málaga: Servicio de Publicaciones de la Universidad. ISBN: 849747-091-5

Since the first conference in Burgos in 2001, every AEDEI academic gathering has had a presiding theme. On that first occasion, it was the perspectives for Irish Studies in the new millennium, followed by the representation of Ireland/s in the conference in Barcelona in 2002, while Irish landscapes was the chosen topic when the conference moved to Almería in 2003. The apparently contradictory terms of humour and tragedy related to Irish culture were the focus for the papers at the 2004 conference in Málaga, collected in this volume. As the editors write in the foreword, humour and tragedy are not so far-removed as might first be thought: "This book looks at both aspects 'humour' and 'tragedy' both independently and together because, as in many other instances, extremes meet and the 
fact is that 'humour' and 'tragedy' are inextricably linked as they are emotions which are complementary and therefore difficult to separate" (9). Irish literature, the editors state, was influential in introducing humour as it is understood today in culture at large, and they mention writers such as Jonathan Swift and Oliver Goldsmith as initiators of this tradition. After reading the collection of articles in this volume one certainly gets the impression that humour is hardly ever an innocent pursuit, and that in the case of literature, complex motives surround the comic presentation of characters and situations. In the dense history of Ireland too, humour is often tinged with satire, irony or resentment, and it has often been the means to escape from dark realities.

The volume is divided into six parts, each dealing with the twin phenomena of humour and tragedy in relation to a particular field of expression: language, fiction, theatre, films, poetry and social sciences. It would be impossible to summarise the contents of all thirty five articles here; I hope these brief comments on a few of them can give an idea of the wide scope of this remarkable book.

The volume opens with an article by Loreto Todd, from the University of Ulster, who tells a personal account of her mother tongue, Hiberno-English, or a "grafted English" as she puts it, because in her community English was incorporated into an Irish substratum. Todd provides a historical account of the evolution of Gaelic in Ireland as well as a linguistic description of the version of Hiberno-English spoken in Tyrone, her county of origin. She believes that Hiberno-English is developing today towards the international, neutral version of English that can be found everywhere.

David M. Clark is the author of a paper on the literary accounts of the 1916 Easter Rising. In his opinion, most accounts of the events belong to the tragic-comedy genre, and he focuses on Sean O'Casey's The Plough and the Stars (1926) as an iconoclastic work of fiction which presents the protagonists of the struggle impelled by personal motives rather than by ideals of liberation for their country. According to Clark, other authors at the end of the $20^{\text {th }}$ century have rekindled the debate on the Rising initiated by O'Casey, and he refers to the novels A Star Called Henry (1999), by Roddy Doyle, and At Swim Two Boys (2001), by Jamie O’Neill.
In a revealing article Constanza del Río Álvaro offers an alternative reading of Flann O'Brien's At Swim-Two-Birds (1939). This narrative, traditionally interpreted in terms of Bakhtin's carnavalesque disruption of literary genres, seems indeed the ideal model for an anti-dogmatic theory of the novel, because of its humour and its mixing of styles and languages. However, Constanza del Río argues, the author himself, a narcissistic joker, hides behind a game that is based on exclusion.

Marisol Morales Ladrón's article discusses Julia O'Faolain's No Country for Young Men (1980), a novel in which the evaluation of the past is a major theme. Morales Ladrón emphasizes the blend of tragic and comic narrative elements, which somehow softens the violent backdrop of the action. One of the novel's main topics is the cyclic course of history, involving women who cannot escape the image Irish society has imposed on them.

In an erudite article, Aída Díaz Bild deals with different theorists who have insisted on the redeeming function of comedy and its power to make human beings accept the awkwardness of life. Conrad Hyers, John Morreall, Marcel Gutwirth, Eric Bentley, Edward Galligan, Wylie Sypher and, of course, Mikhail Bakhtin, are discussed. Díaz Bild makes use of a concept by the Russian thinker, humour as a liberating complement of tragedy, to explain Roddy Doyle's A Star Called Henry.

Asier Altuna-García de Salazar chooses one of the founders of the Abbey Theatre, Lady Gregory, as the focus of his article. Lady Gregory always showed a great interest in Cervantes's Don Quixote, and in her play Sancho's Master (1927) she pays homage to this literary masterpiece. In the opinion of Asier Altuna, this play draws parallelisms between the Sancho/Quixote symbols and the Irish character and history.

Maite Padrós is one of the scholars who writes about the use of humour and tragedy in films, and she focuses on the images offered by recent portrayals of Northern Ireland. In her opinion, film audiences have got an image of Northern Ireland restricted to violence, where the conflict, has often been oversimplified. Maite Padrós believes that the situation has changed since the creation of the Northern Ireland Film and Television Commission in 1997, a board which encourages the production of films which move away from stereotypical images of the region. 